\title{
SYNCHRONIZATION OF AUTHORITY ON INTEGRATED AGRICULTURAL LICENSE SERVICES IN ORDER TO ACTUALIZE THE SOVEREIGNTY OF FOOD SECURITY
}

\author{
Indrawati \\ Administrative Law Department \\ Faculty of Law, Universitas Airlangga, \\ Surabaya, Indonesia \\ indrawati@fh.unair.ac.id
}

\begin{abstract}
The enactment of Act No. 23 of 2014 on Local Government and The Government Regulation No. 18 of 2016 on the Local Government Agency that have a great influence on the change of authority affairs of the local government administration. This condition has an effect on the lack of synchronization between this authority of local government affairs and the institutional of the
\end{abstract} regional apparatus. Furthermore the existing apparatus resources must be reorganized in accordance with the matters which are the regional authority. Agriculture Agency is as one of the organization of regional apparatus whose authority changed after the enactment of Act No. 23 of 2014 on Local Government and The Government Regulation No. 18 of 2016 on the Local Government Agency, it certainly has an impact on the shifting of authority that was formerly only in agriculture, but this is now becoming more widespread with the added affairs of government in the field of Food, Agriculture, Marine and Fisheries in accordance with the capabilities and needs of the region. The institutional restructuring of the Agriculture agency and its authority has implications on the implementation of integrated agricultural licensing services that have not been applied in some areas, because there is still a transition of institutional restructuring of regional apparatus and some regions still do not have relevant regional regulation. Urgency of integrated agricultural licensing services is needed considering that
Indonesia has abundant natural resources such as agriculture, marine and fishery potential as one of the pillars of Indonesian economy. Therefore it is necessary to synchronize integrated agricultural licensing services in order to ensure the stability of food security and restrictions on natural resource management for the sustainability of Indonesia's natural resources balance.

Keywords: synchronization, authority, licensing, agriculture, food security sovereignty

\section{INTRODUCTION}

The Indonesian natural resources and its ecosystems have important positions and roles for life that is a gift of God Almighty, therefore it needs to be managed and utilized for the welfare of Indonesian society. This is in line with the provisions of Article 33 Paragraph (3) of the Indonesian Constitution of 1945 that stated, "The earth and water and natural resources contained therein shall be controlled by the State and used for great prosperity of the people." [1] The world had noted, in 1984 Indonesia had achieved selfsufficiency in rice. The achievement is a great recognition for a country with a very large population, the fifth largest in the world at that time. Nevertheless, the achievement cannot be maintained for a long time, so that Indonesia is forced to import some of its rice needs in order to maintain the food security of its population at a safe level. [2] 
Autonomy has given to the regions is basically directed to accelerate the realization of the welfare of the community through the improvement of services, empowerment, and community participation, as well as enhancement of regional competitiveness by taking into account the principles of democracy, equity, justice, and regional peculiarities. In this case the permits issuance of the agricultural sector which includes licensing in the field of crops, horticulture, farms and plantation is the authority of the Central Government, Provincial Government, and Municipal Government with due regard to the local circumstances and wisdom of each region as regulated in the laws of local government.

The act Number 23 in year 2014 on Regional Government (hereinafter referred to as the Act No. 23 of 2014) as amended the second time by the Act no. 9 Year 2015 (hereinafter referred to as Law No. 9 of 2015) brings some fundamental changes related to the administration of the region. One of the changes is the alteration of authority in the implementation of governmental affairs between levels of government, namely between the Central Government, Provincial Government and Municipal Government consisting of absolute government affairs, concurrent government affairs and general government affairs as regulated in Article 5 of Act no. 23 of 2014.

The alteration of authority has an impact on the existing regional apparatus organization. Currently with the enactment of Act No. 23 of 2014 and Government Regulation Number 18 of 2016 concerning the Local Government Agency (hereinafter referred to as the Government Regulation No. 18 of 2016) there is a lack of synchronization between the government authority affairs with the institutional of the regional apparatus, so it needs to be restructured so that the implementation of government affairs in the region can be implemented effectively and efficiently. In addition, changes in the government authority affairs also affect the personnel or resources of the existing apparatus, which must be reorganized in accordance with the matters which become the regional authority.
In line with above, the institutional restructuring of the regional apparatus has an effect on the delivery of public services to the community. It can be explained that several service / institutional regional apparatus are merged and/or separated as mandated by the Government Regulation No. 18 of 2016 that brings consequences to shifts in working procedures and powers aligned with regional capabilities and rely on regulatory, public service and empowerment functions. The agriculture agency is as one of the regional apparatus organization whose authority changed after the enactment of the Act no. 23 of 2014 and the Government Regulation No. 18 of 2016, it certainly has an impact on the shift of the former authority only in the field of agriculture, but is now becoming more widespread with the added affairs of the government of the field of Food, government affairs of agriculture and government affairs in the field of Marine and Fisheries in accordance with the ability to the needs of the region. The authority of the government affairs implementation in the field of agriculture either between the Central Government, Provincial Government, and Municipal Government is a part of the implementation of public services to the public, in this case one related to integrated agricultural licensing services.

The importance of integrated agricultural licensing service is necessary considering that Indonesia has abundant natural resources such as agriculture, marine and fishery potential as one of the pillars of Indonesian economy. Therefore, it is necessary to have integrated agricultural licensing service in the framework of limitation on the management of natural resources for the sustainability of the balance of natural resources of Indonesia. The agricultural sector has a strategic role in the structure of national economic development. Agriculture is a sector that has a significant role for the Indonesian economy. The agricultural sector absorbed $35.9 \%$ of the total labor force in Indonesia and contributed $14.7 \%$ to GNP Indonesia (BPS, 2012). These facts reinforce agriculture as a vital mega sector for the Indonesian economy. The fertile land is also a potential capital to make Indonesia's agriculture as a source of 
income for its people and also the nation's economic support. [3]

Furthermore one form of government efforts to realize the prosperity of the people, one of them by ensuring the stability of food security. Because food security is the main problem in every country, so ideally the state must guarantee food availability for its citizens in any condition as mandated by the constitution. Given Indonesia's geographical superiority compared to other countries, Indonesia should be able to fulfill food needs independently and sovereignly.[4]

\section{RESEARCH METHODS}

This article is a normative legal research that finds the rule of law, legal principles, and legal doctrines to answer the legal issues faced. This article also uses statute approach by collecting or inventory a number of provisions of legislation especially those that are closely related to the authority in the implementation of integrated agricultural licensing services. In addition, it also uses a conceptual approach (conceptual approach) is the approach that moved from the views and doctrines that developed in the science of law. By studying the views and doctrines of jurisprudence, researchers will find ideas that give birth to legal notions, legal concepts, and legal principles relevant to the issues faced. [5]

In addition, this article uses the statute approach and conceptual approach that is done by going through several stages to answer the existing legal issues. Because the statute approach is still not able to answer the legal issues as a whole and concrete, it takes a conceptual approach that is the views of scholars and legal doctrines to build a strong legal argument. In addition, the legal arguments that have been built in this study are expected to answer the problems that arise in the community and become input for the development of legislation in the future (ius constituendum).

\section{DISCUSSION}

A. The Authority of the Government and the Local Government in Integrated Agricultural Licensing Service in Achieving Food Security
The granting of the widest possible autonomy to the Region shall be carried out on the basis of the principle of a unitary state. In a unitary state the sovereignty exists only in the Government and there is no sovereignty in the Region. Therefore, no matter how much autonomy is granted to the Region, the final responsibility for the implementation of the Local Government will remain in the hands of the Central Government. For that Regional Government in a unitary state is a unity with the National Government. Accordingly, the policies developed and implemented by the Regions are an integral part of national policy. Differentiation lies in how to harness local wisdom, potential, innovation, competitiveness, and creativity to achieve these national goals at the local level which in turn will support the achievement of overall national objectives. In line with the above, the licensing of agriculture is a matter of concurrent government which is included in the government affairs of choice as regulated in Article 12 paragraph (3) of Act No. 23 of 2014. In this case the distribution of concurrent governmental affairs between the Central Government and Provincial Region and District / Municipal is based on the principle of accountability, efficiency, and externalities, as well as national strategic interests.

\section{B. The Regulation of the authority of Integrated Agricultural Licensing Services}

The Government and the Local Government have an obligation to serve every citizen to fulfill his basic rights. Public service system in the field of licensing is an effort to build public trust by public service providers with the conception that public service is an activity that must be done in line with the expectation and demands of all citizens. In addition, also to reinforce the rights and obligations of every citizen, as well as the realization of the responsibility of the Regional Government as state apparatus.

In the case of a number of regulations underlying integrated agricultural licensing services as set forth namely as follows:

1. The Act No. 25 of 2009 on Public Services; 
2. The Act No. 23 of 2014 jo The Act No. 9 of 2015 on concerning Local Government

3. The Act No. 30 of 2014 on Government Administration

4. The President Regulation No 97 of 2014 on the One Door Public Services Integrated

5. The Minister of Agriculture Regulation No: $26 /$ Permentan / HK.140 / 4/2015 on Procedures and Standard Operating Procedures for Providing Technical Recommendations Business License in Field of Agriculture in the Framework of Investment

The important point related to integrate licensing services is in order to get closer and improve services to the community and to shorten the service process in order to realize the fast, easy, cheap, transparent, certain, and affordable services implemented a one-door integrated service. One Stop Integrated Service is an integrated service in one unity of the process starting from the stage of the request up to the completion of the product service through a single door.

The scope of integrated agricultural licensing services includes all licensing and non-licensing services which are the authority of the Government and local government which is implemented by :

a. Government is undertaken by the Capital Investment Coordinating Board for licensing and non-licensing services in the field of investment which is a Government affair;

b. Provincial Government for licensing and nonlicensing services of the compulsory and elected affairs which become provincial affairs; and

c. District / municipality governments for licensing and non-licensing services of compulsory and elected affairs which become districts / municipal affairs.

(The President Regulation No. 97 of 2014 on the Implementation of One-Stop Integrated Service)

Based on the mention above it is very clear that the Government and Local Government have authority in the implementation of integrated licensing services, so there is suitability of the regulation of authority between Act no. 23 of 2014 and the President Regulation No. 97 of 2014.
Type of Agricultural Permits issued by

Government, Provincial and Municipal

Government

\begin{tabular}{|c|c|c|c|c|}
\hline No. & Sub affair & $\begin{array}{c}\text { Central } \\
\text { Government }\end{array}$ & $\begin{array}{c}\text { Provincial } \\
\text { Government }\end{array}$ & Municipal \\
\hline \multirow[t]{5}{*}{1} & \multirow[t]{5}{*}{$\begin{array}{l}\text { Licensing } \\
\text { Agricultur } \\
\text { e Affairs }\end{array}$} & $\begin{array}{l}\text { a. Registration of } \\
\text { feed, animal } \\
\text { products, farm } \\
\text { machinery tools, } \\
\text { veterinary } \\
\text { machine tools and } \\
\text { veterinary } \\
\text { medicines. }\end{array}$ & $\begin{array}{l}\text { a. Issuance of } \\
\text { agricultural } \\
\text { business permit } \\
\text { whose business } \\
\text { activities cross } \\
\text { the regency / } \\
\text { municipality } \\
\text { within 1 one } \\
\text { Provincial } \\
\text { Government. }\end{array}$ & $\begin{array}{l}\text {. Issuance of agricultural } \\
\text { business license whose } \\
\text { business activities are } \\
\text { in regency / } \\
\text { municipality. }\end{array}$ \\
\hline & & \begin{tabular}{l}
\multicolumn{1}{c}{ Issuance of } \\
animal feeding \\
and exclusion \\
recommendations \\
, livestock seeds \\
and crops, feed \\
and feed \\
ingredients out \\
and into \\
Indonesian \\
territory.
\end{tabular} & $\begin{array}{l}\text { p.Issuance of } \\
\text { permit for } \\
\text { construction of } \\
\text { veterinary and } \\
\text { veterinary } \\
\text { health } \\
\text { laboratory in } \\
\text { provincial area. }\end{array}$ & $\begin{array}{l}\text { p. Issuance of production } \\
\text { permit for livestock } \\
\text { and livestock seeds } \\
\text { and seed production, } \\
\text { animal raising facility, } \\
\text { animal hospital / } \\
\text { animal market, } \\
\text { slaughter animal house } \\
\text {. }\end{array}$ \\
\hline & & $\begin{array}{l}\text { c. Determination the } \\
\text { requirements of } \\
\text { laboratory } \\
\text { technical }\end{array}$ & \multirow{3}{*}{$\begin{array}{l}\text { c. Issuance of } \\
\text { livestock } \\
\text { distribution } \\
\text { business } \\
\text { license of } \\
\text { veterinary } \\
\text { medicine. }\end{array}$} & \multirow{3}{*}{$\begin{array}{l}\text { Issuance of retail } \\
\text { business licenses } \\
\text { (stores, retailers, sub- } \\
\text { distributors) of } \\
\text { veterinary medicine. }\end{array}$} \\
\hline & & $\begin{array}{lr}\text { d. Issuance } & \text { of } \\
\text { business permit } \\
\text { for producer } \\
\text { importer } \\
\text { veterinary } \\
\text { medicine. }\end{array}$ & & \\
\hline & & $\begin{array}{l}\text { Registration } \\
\text { permit of } \\
\text { fertilizer formula, } \\
\text { pesticide, alsintan } \\
\text { and veterinary } \\
\text { medicine. } \\
\end{array}$ & & \\
\hline
\end{tabular}

The authority of the Government, Provincial, and Municipal Government in the scope of agriculture is a part of the implementation of public services, in this case related to integrated agricultural licensing services.

\section{Implementation of Issuance of Agricultural Licensing in East Java Province}

The implementation of local government affairs related to the authority of the Agriculture Agency is further regulated in the loca regulation as the realization of the principle of the rule of law and the principle of democracy as described in the table below,

\section{Local Regulation on Institution of} Agriculture Agency

\begin{tabular}{|c|c|c|}
\hline No & Local Regulation & The Institution of Agriculture \\
Agency
\end{tabular}




\begin{tabular}{|r|lr|l|}
\hline & $\begin{array}{l}\text { Composition of Regional } \\
\text { Apparatus }\end{array}$ & $\begin{array}{l}\text { agriculture field and food field } \\
\text { consists of 1 (one) secretariat and 4 } \\
\text { (four) fields. }\end{array}$ \\
\hline 3. & $\begin{array}{l}\text { Local Regulation Surabaya } \\
\text { City No. 14 of 2016 on the } \\
\text { Establishment article 5 subsection (4) capital j } \\
\text { Composition of Regional } \\
\text { Apparatus in Surabaya City }\end{array}$ & $\begin{array}{l}\text { Food Security and Agriculture } \\
\text { Agency which has type A organizes } \\
\text { government affairs in the field of } \\
\text { Food, Governmental affairs of } \\
\text { Agriculture and Government affairs } \\
\text { in the field of Marine and Fisheries; }\end{array}$ \\
\hline 4. & $\begin{array}{l}\text { Local Regulation Sidoarjo } \\
\text { Municipal No 11 of 2016 } \\
\text { Establishment } \\
\text { Composition of Regional } \\
\text { Apparatus in the Municipal } \\
\text { of Sidoarjo }\end{array}$ & $\begin{array}{l}\text { Article 3 capital d number 9 } \\
\text { Food and Agriculture Agency in } \\
\text { Sidoarjo Municipal which has type } \\
\text { A, conducting government affairs in } \\
\text { food and agriculture field; }\end{array}$ \\
\hline 5. & $\begin{array}{l}\text { Local Regulation Trenggalek } \\
\text { Municipal No 17 of 2016 } \\
\text { Establishment } \\
\text { Composition of Regional } \\
\text { Apparatus }\end{array}$ & $\begin{array}{l}\text { Article 5 subsection (4) capital h } \\
\text { Agriculture and Food Agency } \\
\text { which has type A, organizing } \\
\text { Government Affairs in agriculture } \\
\text { and Food Governance Affairs; }\end{array}$ \\
\hline
\end{tabular}

Based on the above, the Act No. 23 of 2014 as amended the second time by Act No. 9 of 2015 and Government Regulation No. 18 of 2016 brings a great influence on the change of authority affairs of the local government administration, so that required the restructuring of regional institutions that ultimately have an impact on the implementation of public services for the community. The integrated agricultural licensing service is a part of concurrent government affair which is optional matter that has not been applied in some areas, because there is still a transition of institutional restructuring of regional apparatus and some areas still do not have relevant local regulation. In addition, the absence of local regulation governing integrated agricultural licensing services will result in the lack of synchronization and disharmony of the authority of the Government, Provincial and Municipal. Nevertheless, the urgency of integrated agricultural licensing service is necessary considering that Indonesia has abundant natural resources such as agriculture, marine and fishery potential as one of the pillars of Indonesian economy. Therefore, it is necessary to have an integrated agricultural licensing service within the framework of limitation on natural resource management for the sustainability of Indonesia's natural resource balance and ensuring the stability of food security.

\section{ACKNOWLEDGMENTS}

This article was supported by Law Faculty of Universitas Airlangga who has provided funding for the research of this article.

\section{CONCLUSION}

The integrated agricultural licensing service is a part of concurrent government affair which is optional matter that has not been applied in some areas, because there is still a transition of institutional restructuring of regional apparatus and some areas still do not have relevant local regulation. In addition, the absence of local legal products governing integrated agricultural licensing services will result in the lack of synchronization and disharmony of authority of the Government, Provincial and District / City Government.

\section{References}

[1] Suparto Wijoyo, et all., 2015, Sinkronisasi Wewenang Pengelolaan Sumber Daya Air Dalam Rangka Mewujudkan Kedaulatan Sumber Daya Air, Penelitian RKAT FH UNAIR TAhun 2015, FH UNAIR, h. 1.

[2] E. Herman Khaeron, 2012, Politik Ekonomi Pangan Menggapai Kemandirian, Mewujudkan Kesejahteraan, Cidesindo, Jakarta, h.12

[3] A. Handoko Eko Prihardiyan, Potensi Sektor Pertanian di Indonesia, http://handokoberbagi.blogspot.co.id/2014/01/po tensi-sektor-pertanian-di-indonesia.html,10 April 2017, 08.00 WIB.

[4] Indrawati,et.all, 2013, Kebijakan Pemerintah (Beleidsregel) Dalam Pengelolaan Anggaran Negara Terhadap Subsidi Pupuk Dalam Rangka Mewujudkan Kedaulatan Pangan, Penelitian RKAT FH UNAIR, 2013, hal. 1.

[5] Peter Mahmud Marzuki, 2005, Penelitian Hukum, Kencana Prenada Media Group, Jakarta, h. 35 . 